\title{
Effects of Pressure and Other Variables on Determinations of Octane Number ${ }^{1}$
}

\author{
By William J. Levedahl
}

\begin{abstract}
Knock ratings made at altitude differ significantly from those made at sea level by both the ASTM Motor and Research Methods. Experiments were made in an altitude chamber to determine the effect on measured values of octane number of ambient pressure, engine speed, inlet mixture temperature, spark advance, knock intensity, exhaust back pressure, and diameter of carburetor venturi. The results indicate that no changes short of supercharging the engines will give ratings identical with those determined at sea level.
\end{abstract}

\section{Introduction}

After the adoption in 1933 of the ASTM Motor Method for determining the octane numbers of fuels, it was found that the ratings obtained by various laboratories differed somewhat, and that the differences increased with the altitudes of the test laboratories. In 1937, by throttling the intake and pumping down on the exhaust, Holaday and Moore [1] ${ }^{2}$ showed that ratings decreased with decreasing charge density. They found that, at constant compression ratio, the knock intensity at $25 \mathrm{in} . \mathrm{Hg}$ with a ${ }^{3 / 4}$-in. venturi was equal to that at sea level with a $9 / 16$-in. venturi and throttle plate. The subsequent use of larger venturis resulted in better agreement among ratings made at altitudes up to $5,000 \mathrm{ft}$.

The problem became more serious in 1939, when the Research Method was adopted by the Cooperative Fuel Research Committee as a supplementary method of rating fuels. Tests showed that neither changing the size of venturis nor varying the spark advance would compensate satisfactorily for altitude.

In 1941 this Bureau, in cooperation with the CFR Motor Fuels Division, conducted tests which indicated [2] that, with the fuels available at that time, the effect of altitude on knock ratings could be eliminated by operating at constant knock intensity. Blends of secondary reference fuels $(\mathrm{A}-6$ and $\mathrm{C}-12)$ were used in this work.

A series of "guide curves" was established to indicate the proper compression ratios for maintaining standard knock intensity at all barometric pressures and octane numbers. These curves (one curve for each octane level) are parallel straight lines, one for each octane number, the slopes of which are 0.030 and $0.020 \mathrm{in.} / \mathrm{in} \mathrm{Hg}$ for the Motor Method and for the Research Method, respectively. Application of this method in various laboratories gave ratings that were essentially independent of the altitude of the test engine.

With the development of the Detonation Meter, Model 501, as an alternate to the bouncing pin, a second set of guide curves was established at this Bureau in 1948 for use with the $\% / 16$-in. venturi.

This project was a joint undertaking of the American Petroleum Institute and the National Bureau of Standards.

2 Figures in brackets indicate the literature references at the end of this paper.
More recently, two developments have led to the belief that the empirical method outlined above is not wholly satisfactory in insuring uniformity of ratings. These are changes in the composition of motor gasoline due to the method of manufacture and the more general use of the primary reference fuels, $n$-heptane and isooctane, instead of secondary reference fuels. Current gasolines are more sensitive to engine operating conditions than earlier fuels, and hence show greater differences in ratings by the Motor and Research Methods. The secondary reference fuels behave similarly with respect to the primary reference fuels.

Hence the American Petroleum Institute and the National Bureau of Standards undertook a further investigation of the problem of altitude ratings in 1949. The objectives of the program were to establish the magnitudes of rating variation with pressure for several typical fuels, to check the guide curves, and to investigate the individual effects of certain operating variables.

\section{Test Equipment}

The engine used in this project was a standard ASTM-CFR knock rating engine [3], with a single cylinder of $3 \frac{1 / 4}{4}-\mathrm{in}$. bore and $4 \frac{1}{2}$-in. stroke. The compression ratio could be varied between $4: 1$ and 10:1 by raising or lowering the cylinder, and determined by means of a micrometer. All settings and operating conditions specified in reference [3] were followed, excepting only the cases for which deviations are specified herein. Both the bouncing pin and the alternate Model 501 Detonation Meter were used in the present work.

The air-consumption tests were made with a multiple-orifice air meter developed by the Ethyl Corporation. The test engine was installed in a conventional altitude chamber large enough to accommodate all equipment and two operators. A gate valve in the exhaust line was used to control exhaust back pressure in some tests. The coolant condenser was vented outside the chamber, so that the same boiling point prevailed at all altitudes. Chamber pressure was determined by subtracting the reading of a U-tube mercury manometer connected between the chamber and the atmosphere from the barometric 
pressure. A sensitive aircraft altimeter was then referred to as an aid in maintaining constant pressure.

\section{Altitude Chamber Tests}

\section{Effect of Pressure on Octane Number Ratings}

Standard procedures [3] were used throughout the tests unless otherwise noted. Prior to each series of runs at reduced pressure, the engine and knock detection apparatus were "standardized" with the chamber open. Subsequent tests were made at progressively lower pressures, keeping standard knock intensity by changing the compression ratio without further adjustment of the Detonation Meter or bouncing pin.

The ten fuels used were carefully selected so that the results would cover a wide range of fuel types and octane numbers. These are listed and numbered in table 1.

TABLE 1. Fuels used in test program

\begin{tabular}{|c|c|c|c|}
\hline \multirow{2}{*}{ Fuel } & \multirow{2}{*}{ Fuel composition } & \multicolumn{2}{|c|}{$\begin{array}{l}\text { Nominal octane } \\
\text { number }\end{array}$} \\
\hline & & $\begin{array}{l}\text { Motor } \\
\text { Method }\end{array}$ & $\begin{array}{l}\text { Research } \\
\text { Method }\end{array}$ \\
\hline 1 & $60 \%$ X-6, $40 \%$ n-heptane_. & 69.6 & 80.3 \\
\hline 2 & $86 \% \mathrm{X}-6,14 \%$ n-heptane $\ldots$ & 90.0 & $>100$ \\
\hline 3 & $\begin{array}{l}52 \% \text { isooctane, } 48 \% \text { n-heptane, } 2 \mathrm{ml} \text { TEL } \\
\text { blend/gallon. }\end{array}$ & 75.6 & 74. 7 \\
\hline 4 & $\begin{array}{l}74 \% \text { isooctane, } 26 \% \text {-heptane, } 2 \mathrm{ml} \text { TEL } \\
\text { blend/gallon- }\end{array}$ & \multirow[t]{3}{*}{90.8} & \multirow[t]{3}{*}{ 89. 9} \\
\hline 5 & $\begin{array}{l}80 \text { octane number commercial gasoline: cata- } \\
\text { lytic cracked, thermal cracked, and } \\
\text { straight-run components without lead. }\end{array}$ & & \\
\hline 6 & $\begin{array}{l}80 \text { octane number commercial gasoline: cata- } \\
\text { lytic cracked, thermal cracked, and } \\
\text { straight-run components with lead. }\end{array}$ & & \\
\hline 7 & $80 \%$ diisobutylene, $20 \% n$-heptane........ & & \\
\hline 8 & $51 \% \mathrm{X}-6,49 \%$-heptane & 60.8 & 69.9 \\
\hline 9 & $70 \% \mathrm{X}-6,30 \%$ n-heptane $\ldots$ & 77.9 & 89.9 \\
\hline 10 & C-14 secondary reference fuel & 70.0 & 72.4 \\
\hline
\end{tabular}

The results obtained by the Motor Method, using test fuels 1 through 7 and both the bouncing pin and the Detonation Meter, are given in table 2 and shown graphically in figure 1 . A carburetor venturi, $9 / 16$ in. in diameter, was used at ambient pressures of $27 \mathrm{in}$. $\mathrm{Hg}$ and above, and a $3 / 4-$ in. venturi was used at lower pressures. Filled circles indicate results with the bouncing pin, and the open circles are for the Detonation Meter.

TABLE 2. Tariation of Motor Method ratings with pressure

\begin{tabular}{|c|c|c|c|c|c|}
\hline \multirow{2}{*}{$\begin{array}{l}\text { Chamber } \\
\text { pressure }\end{array}$} & \multirow{2}{*}{$\begin{array}{l}\text { Venturi } \\
\text { diameter }\end{array}$} & \multicolumn{2}{|c|}{501 Detonation Meter } & \multicolumn{2}{|c|}{ Bouncing pin } \\
\hline & & $\begin{array}{c}\text { Rating } \\
\text { octane No. }\end{array}$ & $\begin{array}{l}\text { Microm- } \\
\text { eter }\end{array}$ & $\begin{array}{c}\text { Rating } \\
\text { octane No. }\end{array}$ & $\begin{array}{l}\text { Microm- } \\
\text { eter }\end{array}$ \\
\hline \multicolumn{6}{|c|}{ FUEL 1} \\
\hline $\begin{array}{l}\text { in. } \mathrm{Hg} \\
29.68 \\
29.64 \\
29.0 \\
28.0 \\
27.0\end{array}$ & $\begin{array}{l}\text { in. } \\
9 / 16 \\
9 / 16 \\
9 / 16 \\
9 / 16 \\
9 / 16\end{array}$ & $\begin{array}{l}70.1 \\
70.8 \\
70.0 \\
69.2\end{array}$ & $\begin{array}{l}\text { in. } \\
0.510 \\
-.484 \\
.450 \\
.420\end{array}$ & $\begin{array}{l}69.4 \\
69.4 \\
68.5 \\
68.2\end{array}$ & $\begin{array}{r}\text { in. } \\
0.527 \\
.509 \\
.479 \\
.449\end{array}$ \\
\hline $\begin{array}{l}26.0 \\
25.0 \\
23.0 \\
21.0\end{array}$ & $\begin{array}{l}3 / 4 \\
3 / 4 \\
3 / 4 \\
3 / 4\end{array}$ & $\begin{array}{l}68.9 \\
68.6 \\
68.0 \\
\ldots\end{array}$ & $\begin{array}{l}.506 \\
.462 \\
.391 \\
.\end{array}$ & $\begin{array}{l}69.3 \\
68.9 \\
68.2 \\
67.8\end{array}$ & $\begin{array}{l}.499 \\
.472 \\
.398 \\
.314\end{array}$ \\
\hline
\end{tabular}

TABle 2. Tariation of Motor Method ratings with pressureContinued

\begin{tabular}{|c|c|c|c|c|c|}
\hline \multirow{2}{*}{$\begin{array}{l}\text { Chamber } \\
\text { pressure }\end{array}$} & \multirow{2}{*}{$\begin{array}{c}\text { Venturi } \\
\text { diameter }\end{array}$} & \multicolumn{2}{|c|}{501 Detonation Meter } & \multicolumn{2}{|c|}{ Bouncing pin } \\
\hline & & $\begin{array}{l}\text { Rating } \\
\text { octane No. }\end{array}$ & $\begin{array}{l}\text { Microm- } \\
\text { eter }\end{array}$ & $\begin{array}{c}\text { Rating } \\
\text { octane No. }\end{array}$ & $\begin{array}{c}\text { Microm- } \\
\text { eter }\end{array}$ \\
\hline
\end{tabular}

FUEL 2

\begin{tabular}{|l|l|l|l|l|l|}
\hline 29.67 & $9 / 16$ & 90.1 & 0.278 & & \\
29.64 & $9 / 16$ &.- .5 & .260 & 90.1 & 0.271 \\
29.0 & $9 / 16$ & 89.9 & .250 & .253 \\
28.0 & $9 / 16$ & 89.3 & .220 & 89.3 & .223 \\
27.0 & $9 / 16$ & 88.9 & .200 & 88.4 & .193 \\
26.0 & $3 / 4$ & 89.0 & .275 & 89.4 & .236 \\
25.0 & $3 / 4$ & 8.6 & .250 & 89.2 & .205 \\
23.0 & $3 / 4$ & 87.7 & .191 & 88.1 & .165 \\
21.0 & $3 / 4$ & 87.5 & .137 & 86.6 & .122 \\
\hline
\end{tabular}

FUEL 3

\begin{tabular}{l|l|l|l|l|l|}
\hline & & & & \\
29.68 & $9 / 16$ & 76.5 & 0.455 & 76.0 & 0.462 \\
29.60 & $9 / 16$ & -5.7 & .437 & 75.8 & .444 \\
29.0 & $9 / 16$ & 76.7 & .407 & 76.4 & .414 \\
28.0 & $9 / 16$ & 76.9 & .357 & 76.7 & .376 \\
27.0 & $9 / 16$ & 77.0 & & \\
26.0 & $3 / 4$ & 77.3 & .442 & 77.1 & .415 \\
25.0 & $3 / 4$ & 77.1 & .402 & 77.1 & .404 \\
23.0 & $3 / 4$ & 77.1 & .324 & 77.5 & .330 \\
21.0 & $3 / 4$ & 77.8 & .228 & 77.5 & .245 \\
\hline
\end{tabular}

FUEL 4

\begin{tabular}{l|l|l|l|l|l|}
\hline & & & \\
29.79 & $9 / 16$ & 91.1 & 0.265 &.- .9 & 0.271 \\
29.64 & $9 / 16$ & -1.0 & .244 & 90.9 & .253 \\
29.0 & $9 / 16$ & 91.0 & .214 & 90.9 & .223 \\
27.0 & $9 / 16$ & 91.4 & .184 & 91.7 & .193 \\
26.0 & 916 & 91.8 & .14 & \\
25.0 & $3 / 4$ & 91.5 & .233 & 91.0 & .232 \\
23.0 & $3 / 4$ & 91.6 & .214 & 91.0 & .180 \\
21.0 & $3 / 4$ & 92.7 & .140 & 92.1 & .109 \\
& $3 / 4$ & 92.8 & .080 & 92.8 & .014 \\
\hline
\end{tabular}

FUEL 5

\begin{tabular}{|c|c|c|c|c|c|}
\hline $\begin{array}{l}29.74 \\
29.67 \\
29.0 \\
28.0 \\
27.0\end{array}$ & $\begin{array}{l}9 / 16 \\
9 / 16 \\
9 / 16 \\
9 / 16 \\
9 / 16\end{array}$ & $\begin{array}{l}80.8 \\
80.6 \\
80.5 \\
79.8\end{array}$ & $\begin{array}{r}0.408 \\
.387 \\
.350 \\
.314\end{array}$ & $\begin{array}{l}81.0 \\
81.2 \\
80.6 \\
80.1\end{array}$ & $\begin{array}{r}0.407 \\
.378 \\
.357 \\
.322\end{array}$ \\
\hline $\begin{array}{l}26.0 \\
25.0 \\
23.0 \\
21.0\end{array}$ & $\begin{array}{l}3 / 4 \\
3 / 4 \\
3 / 4 \\
3 / 4\end{array}$ & $\begin{array}{l}80.8 \\
81.3 \\
79.4 \\
79.1\end{array}$ & $\begin{array}{l}375 \\
.329 \\
.264 \\
.194\end{array}$ & $\begin{array}{l}81.4 \\
80.9 \\
80.3 \\
78.7\end{array}$ & $\begin{array}{l}.357 \\
.322 \\
.253 \\
.202\end{array}$ \\
\hline \multicolumn{6}{|c|}{ FUEL 6} \\
\hline $\begin{array}{l}29.74 \\
29.67 \\
29.0 \\
28.0 \\
27.0\end{array}$ & $\begin{array}{l}9 / 16 \\
9 / 16 \\
9 / 16 \\
9 / 16 \\
9 / 16\end{array}$ & $\begin{array}{l}80.3 \\
80.0 \\
79.7 \\
79.2\end{array}$ & $\begin{array}{r}0.408 \\
.387 \\
.350 \\
.314\end{array}$ & $\begin{array}{l}80.1 \\
79.9 \\
79.7 \\
79.3\end{array}$ & $\begin{array}{r}0.407 \\
.391 \\
.356 \\
.329\end{array}$ \\
\hline $\begin{array}{l}26.0 \\
25.0 \\
23.0 \\
21.0\end{array}$ & $\begin{array}{l}3 / 4 \\
3 / 4 \\
3 / 4 \\
3 / 4\end{array}$ & $\begin{array}{l}80.0 \\
79.8 \\
79.4 \\
78.7\end{array}$ & $\begin{array}{l}.377 \\
.336 \\
.250 \\
.194\end{array}$ & $\begin{array}{l}80.7 \\
80.6 \\
80.0 \\
78.7\end{array}$ & $\begin{array}{r}.358 \\
.323 \\
.257 \\
.197\end{array}$ \\
\hline \multicolumn{6}{|c|}{ FUEL 7} \\
\hline $\begin{array}{l}29.74 \\
29.60 \\
29.0 \\
28.0 \\
27.0\end{array}$ & $\begin{array}{l}9 / 16 \\
9 / 16 \\
9 / 16 \\
9 / 16 \\
9 / 16\end{array}$ & $\begin{array}{l}83.6 \\
83.3 \\
83.0 \\
82.5\end{array}$ & $\begin{array}{r}0.377 \\
-.356 \\
.317 \\
.285\end{array}$ & $\begin{array}{l}83.8 \\
83.6 \\
83.4 \\
83.2\end{array}$ & $\begin{array}{r}0.363 \\
.357 \\
.328 \\
.283\end{array}$ \\
\hline $\begin{array}{l}26.0 \\
25.0 \\
23.0 \\
21.0\end{array}$ & $\begin{array}{l}3 / 4 \\
3 / 4 \\
3 / 4 \\
3 / 4\end{array}$ & $\begin{array}{l}83.8 \\
83.4 \\
82.9 \\
81.5\end{array}$ & $\begin{array}{l}.329 \\
.300 \\
.228 \\
.175\end{array}$ & $\begin{array}{l}85.1 \\
84.2 \\
83.5 \\
81.6\end{array}$ & $\begin{array}{r}.330 \\
.308 \\
.245 \\
.188\end{array}$ \\
\hline
\end{tabular}




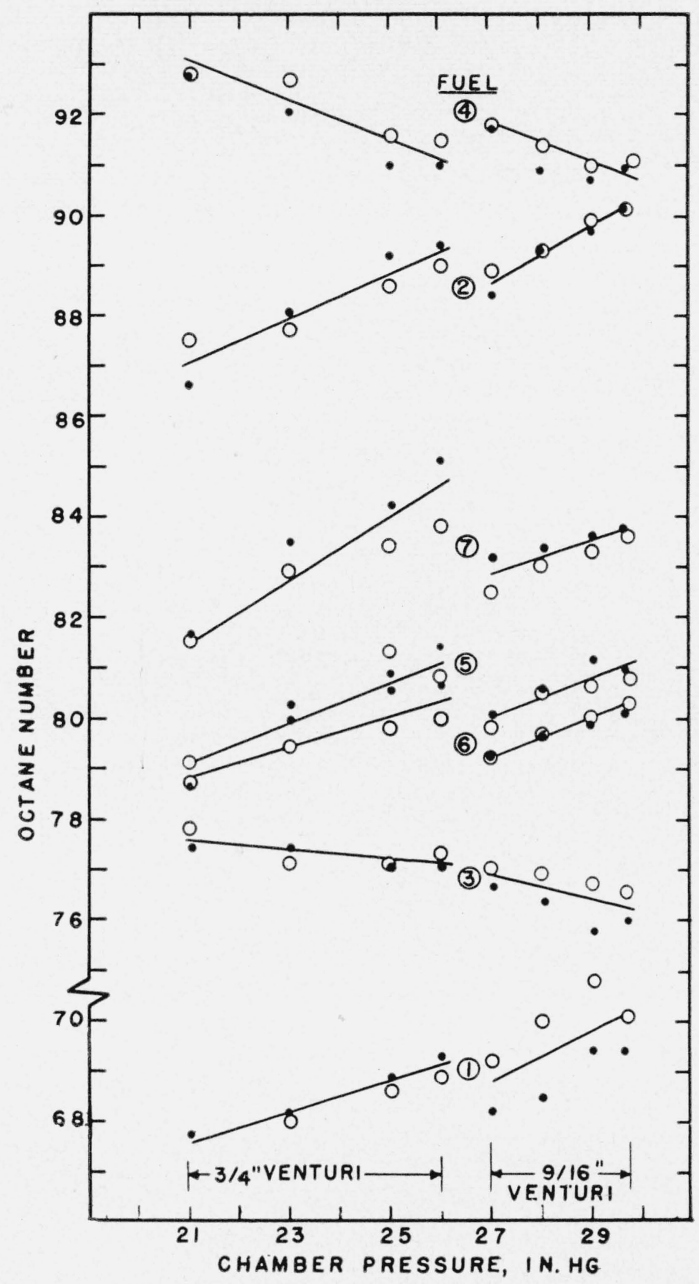

FIGURE 1. Variation of octane rating with altitude by the ASTM D 357 Motor Method.

For composition of the seven fuels, see table 1.

0 , Rated with Detonation Meter, Model 501; - rated with bouncing pin.

As can be seen in figure 1 , the octane number ratings of the leaded primary reference fuels (3 and 4) decrease with increasing pressure, whereas those of the other five fuels increase with the pressure. In most cases the rating at $26 \mathrm{in} . \mathrm{Hg}$ with the $3 / 4$-in. venturi is approximately equal to the rating at one atmosphere with the $9 / 16$-in. venturi.

Only the $9 / 16$-in. venturi was used in the Research Method tests, and runs were made at sea level, 27, 24, and 21-in. $\mathrm{Hg}$ pressure. Fuels 3 and 5 were run only at sea level and $21-\mathrm{in} . \mathrm{Hg}$. All fuel types tested by both methods showed the same trends by the Research Method as by the Motor Method. Secondary reference fuel $\mathrm{C}-14$ increased in rating about 0.1 octane unit per inch of mercury pressure drop. Table 3 and figure 2 give the Research Method ratings at the various pressures for the fuels tested.

Constant knock intensity "guide curves" of micrometer setting versus barometric pressure were then determined for the Detonation Meter by both
TABLE 3. Variation of Research Method ratings with pressure

\begin{tabular}{|c|c|c|c|c|c|c|}
\hline \multirow{3}{*}{$\begin{array}{l}\text { Chamber } \\
\text { pressure }\end{array}$} & \multicolumn{4}{|c|}{ Rated with primary reference fuels } & \multirow{2}{*}{\multicolumn{2}{|c|}{$\begin{array}{c}\begin{array}{c}\text { Rated with second- } \\
\text { ary reference fuels }\end{array} \\
\begin{array}{c}501 \text { Detonation } \\
\text { Meter }\end{array}\end{array}$}} \\
\hline & \multicolumn{2}{|c|}{$\begin{array}{l}501 \text { Detonation } \\
\text { Meter }\end{array}$} & \multicolumn{2}{|c|}{ Bouncing pin } & & \\
\hline & $\begin{array}{c}\text { Rating } \\
\text { octane } \\
\text { no. }\end{array}$ & $\begin{array}{c}\text { Microm- } \\
\text { eter }\end{array}$ & $\begin{array}{c}\text { Rating } \\
\text { octane } \\
\text { no. }\end{array}$ & $\begin{array}{l}\text { Microm- } \\
\text { eter }\end{array}$ & $\begin{array}{c}\text { Rating } \\
\text { octane } \\
\text { no. }\end{array}$ & $\begin{array}{l}\text { Microm- } \\
\text { eter }\end{array}$ \\
\hline \multicolumn{7}{|c|}{ FUEL 3} \\
\hline $\begin{array}{l}\text { in. } \mathrm{Hg} \\
29.64 \\
21.0\end{array}$ & $\begin{array}{l}74.5 \\
76.6\end{array}$ & $\begin{array}{l}\text { in. } \\
0.415 \\
.228\end{array}$ & - & in. & - & in. \\
\hline \multicolumn{7}{|c|}{ FUEL 4} \\
\hline $\begin{array}{l}29.67 \\
29.62 \\
29.74 \\
27.0 \\
24.0 \\
21.0\end{array}$ & $\begin{array}{c}91.1 \\
-\cdots 91.6 \\
92.2 \\
92.3\end{array}$ & \begin{tabular}{l}
0.282 \\
\hdashline .221 \\
.144 \\
.070
\end{tabular} & $\begin{array}{l}91.2 \\
91.5 \\
91.8 \\
91.9\end{array}$ & $\begin{array}{l}0.270 \\
.238 \\
.164 \\
.096\end{array}$ & $\begin{array}{l}-\ldots . .- \\
91.3 \\
91.6 \\
92.1 \\
92.3\end{array}$ & $\begin{array}{l}0.288 \\
.219 \\
.145 \\
.067\end{array}$ \\
\hline \multicolumn{7}{|c|}{ FUEL 5} \\
\hline $\begin{array}{l}29.64 \\
21.0\end{array}$ & $\begin{array}{l}91.5 \\
89.9\end{array}$ & $\begin{array}{r}0.274 \\
.101\end{array}$ & - & -..... & -.... & - \\
\hline \multicolumn{7}{|c|}{ FUEL 6} \\
\hline $\begin{array}{l}29.66 \\
27.0 \\
24.0 \\
21.0\end{array}$ & $\begin{array}{l}89.9 \\
89.5 \\
89.3 \\
88.5\end{array}$ & $\begin{array}{r}0.292 \\
.232 \\
.168 \\
.136\end{array}$ & $\begin{array}{l}90.7 \\
90.0 \\
89.2 \\
88.8\end{array}$ & $\begin{array}{r}0.290 \\
.235 \\
.185 \\
.115\end{array}$ & $\begin{array}{l}89.9 \\
89.7 \\
89.1 \\
88.7\end{array}$ & $\begin{array}{r}0.300 \\
.245 \\
.175 \\
.106\end{array}$ \\
\hline \multicolumn{7}{|c|}{ FUEL 8} \\
\hline $\begin{array}{l}29.72 \\
29.63 \\
29.62 \\
27.0 \\
24.0 \\
21.0\end{array}$ & \begin{tabular}{c}
70.2 \\
\hdashline.-- \\
69.4 \\
68.0 \\
67.6
\end{tabular} & $\begin{array}{l}0.434 \\
-. .- \\
.377 \\
.283 \\
.192\end{array}$ & $\begin{array}{l}70.4 \\
69.4 \\
68.8 \\
67.8\end{array}$ & $\begin{array}{l}. \\
0.442 \\
.328 \\
.256\end{array}$ & $\begin{array}{l}70.7 \\
-70.4 \\
69.8 \\
69.1\end{array}$ & $\begin{array}{l}0.426 \\
.381 \\
.324 \\
.268\end{array}$ \\
\hline \multicolumn{7}{|c|}{ FUEL 9} \\
\hline $\begin{array}{l}29.67 \\
29.66 \\
29.74 \\
27.0 \\
24.0 \\
21.0\end{array}$ & \begin{tabular}{l}
90.2 \\
\hdashline 89.9 \\
88.9 \\
87.4
\end{tabular} & $\begin{array}{l}0.292 \\
-. .2 \\
.239 \\
.172 \\
.070\end{array}$ & $\begin{array}{l}90.4 \\
89.7 \\
88.6 \\
87.3\end{array}$ & $\begin{array}{l}0.290 \\
.235 \\
.180 \\
.129\end{array}$ & $\begin{array}{l}90.7 \\
90.2 \\
88.8 \\
87.6\end{array}$ & $\begin{array}{l}0 . . .- \\
0.294 \\
.178 \\
.110\end{array}$ \\
\hline \multicolumn{7}{|c|}{ FUEL 10} \\
\hline $\begin{array}{l}29.64 \\
27.0 \\
24.0 \\
21.0\end{array}$ & $\begin{array}{l}72.3 \\
72.5 \\
71.7 \\
71.4\end{array}$ & $\begin{array}{l}0.424 \\
.362 \\
.308 \\
.258\end{array}$ & \begin{tabular}{l}
$\cdots+\cdots$ \\
$\cdots \cdots$ \\
\hdashline$-\cdots$
\end{tabular} & $\begin{array}{l}-\cdots \\
\cdots \cdots \\
\cdots \cdots\end{array}$ & 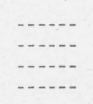 & 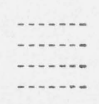 \\
\hline
\end{tabular}

the Motor and Research Methods (figs. 3 and 4, tables 4 and 5). These curves show the cylinder height necessary to maintain standard knock intensity (a reading of 55 on the knockmeter) with primary reference fuel blends of 40 to 100 octane number.

The solid lines on the figures show the values obtained in these tests, while the dotted lines are those defined in reference [3]. Since no Detonation Meter guide curves have been adopted for use with the $3 / 4$-in. venturi, the dotted lines here show the bouncing pin curves. 


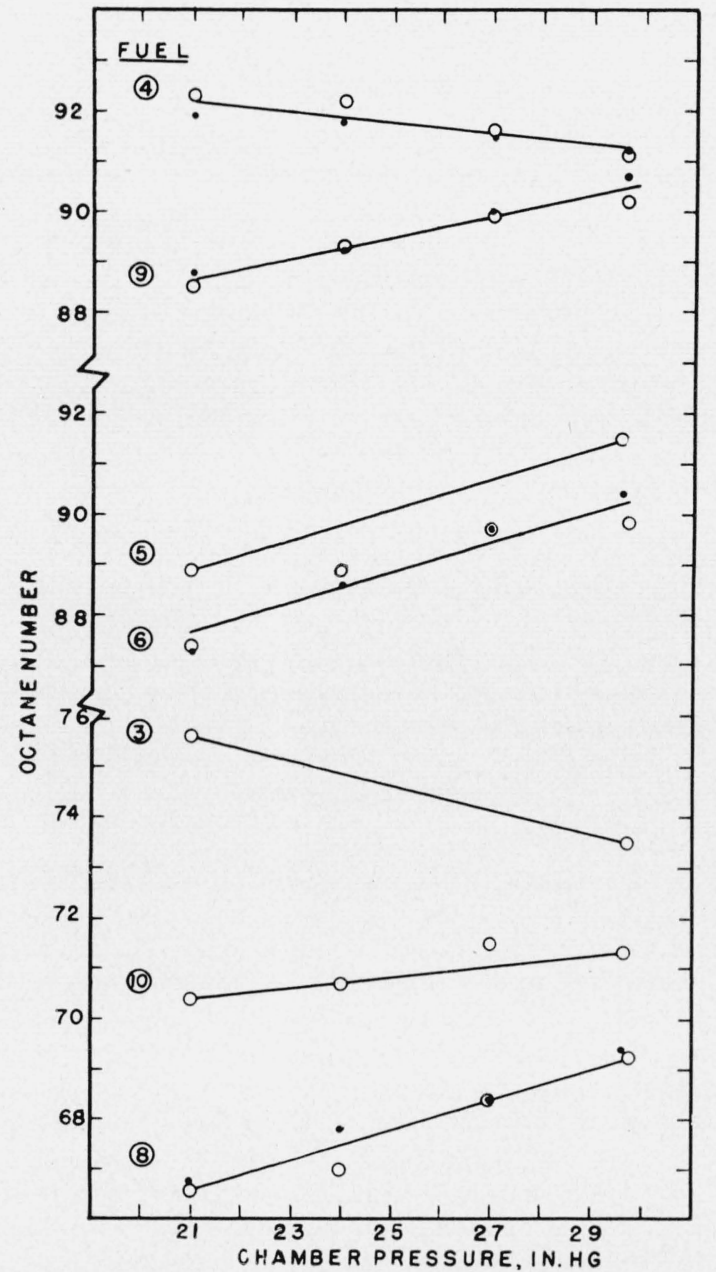

FIGURE 2. Variation of octane rating with altitude by the ASTM D 908 Research Method.

For composition of the seven fuels, see table 1

0 , Rated with Detonation Meter, Model 501; - , rated with bouncing pin.

TABLE 4. Motor Method guide curves for various pressures with the Detonation Meter, Model 501

\begin{tabular}{|c|c|c|c|c|c|c|}
\hline \multirow{4}{*}{ Octane number } & \multicolumn{6}{|c|}{ Chamber pressure, in. $\mathrm{Hg}$} \\
\hline & \multicolumn{3}{|c|}{$9 / 16$-in. venturi } & \multicolumn{3}{|c|}{ 3/4-in. venturi } \\
\hline & 29. 68 & 28.5 & 27.5 & 27.0 & 24.0 & 21.0 \\
\hline & \multicolumn{6}{|c|}{ Micrometer setting } \\
\hline $\begin{array}{l}40 \\
50 \\
60 \\
70 \\
80 \\
90 \\
100\end{array}$ & $\begin{array}{c}i n . \\
0.669 \\
.625 \\
.578 \\
.518 \\
.425 \\
.299 \\
.202\end{array}$ & $\begin{array}{r}\text { in. } \\
0.632 \\
.595 \\
.545 \\
.488 \\
.390 \\
.273 \\
.184\end{array}$ & $\begin{array}{c}\text { in. } \\
0.604 \\
.569 \\
.512 \\
.453 \\
.350 \\
.235 \\
.157\end{array}$ & $\begin{array}{r}\text { in. } \\
0.708 \\
.666 \\
.613 \\
.552 \\
.467 \\
.365 \\
.272\end{array}$ & $\begin{array}{c}\text { in. } \\
0.592 \\
.550 \\
.503 \\
.447 \\
.361 \\
.251 \\
.173\end{array}$ & $\begin{array}{r}\text { in. } \\
0.457 \\
.432 \\
.390 \\
.326 \\
.240 \\
.156 \\
.083\end{array}$ \\
\hline
\end{tabular}

These results indicate that standard guide curves do not have sufficient slope, particularly at the lower octane levels. No conclusions should be drawn relative to the guide curve spacing for the
TABLE 5. Research Method guide curves for various pressures with Detonation Meter, Model 501

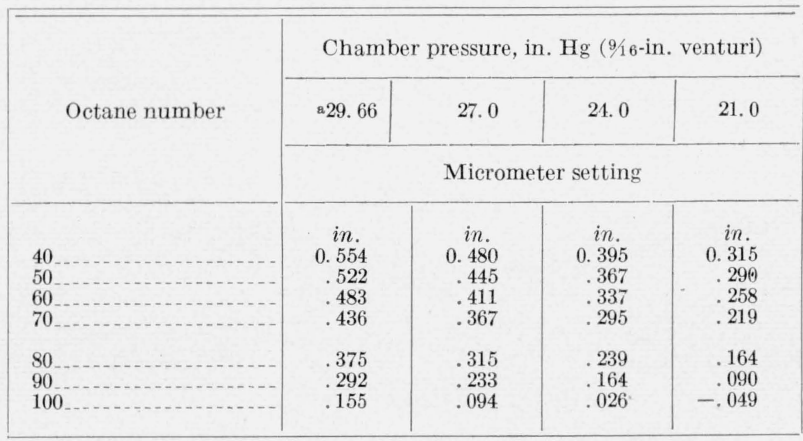

^Pressure for fuels of 80,90 , and 100 octane number was $29.64 \mathrm{in}$. $\mathrm{Hg}$.

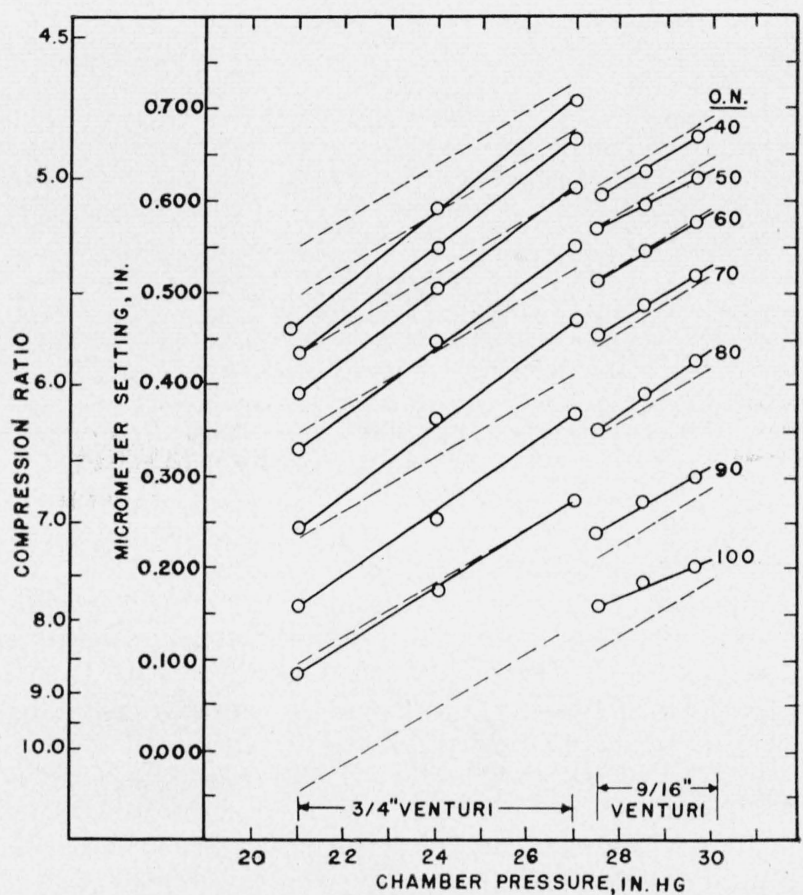

FIGURE 3. Motor Method guide curves for various altitudes with Detonation Meter, Model 501.

The solid lines represent data obtained in this research; the broken lines are the guide curves currently in use [3].

Motor Method, as the customary practice of changing the Detonation Meter setting at the higher octane levels was not adhered to in these tests.

\section{Effects of Pressure on Air Consumption (Motoring ${ }^{3}$ Only)}

It was thought that failure to obtain the same ratings at all altitudes might result primarily from the differences in air consumption. Therefore, air consumption while motoring was measured under both Motor and Research Method conditions at pressures down to $21 \mathrm{in}$. Hg. The effects of oversized venturis, a high-lift camshaft, and change in exhaust back pressure were also determined. The high-lift camshaft used had an inlet cam that increased the

\footnotetext{
3 "Motoring" designates nonfiring operation of the engine.
} 


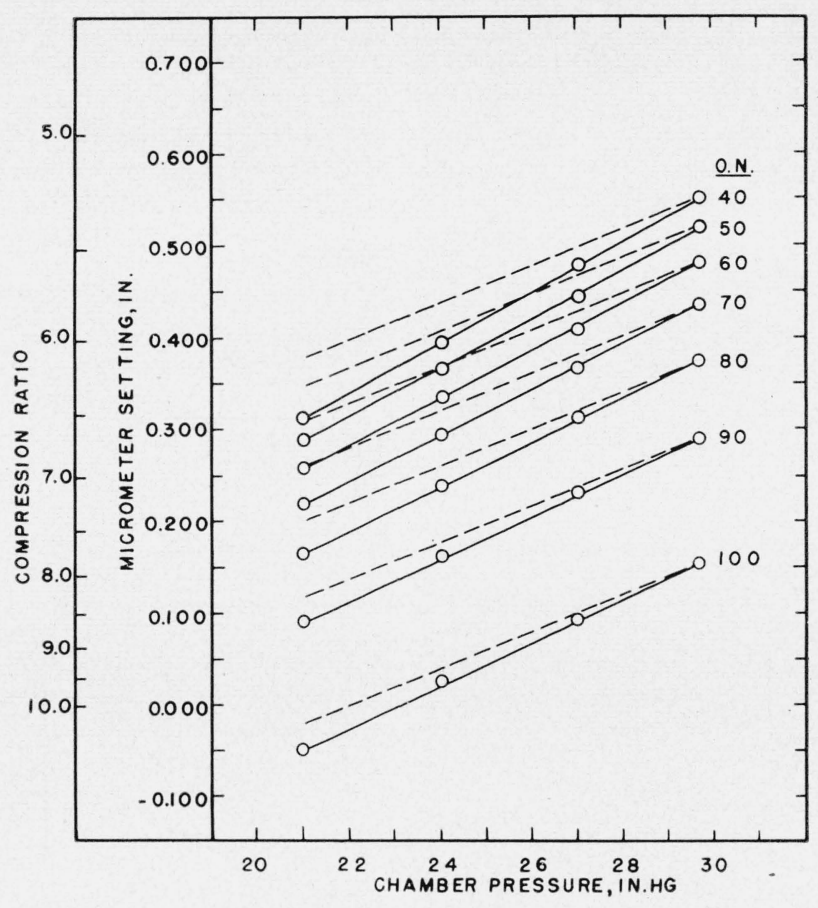

FIgURE 4. Research Method guide curves for various altitudes with Detonation Meter, Model 501.

The solid lines represent data obtained in this research; the broken lines are the guide curves currently in use [3].

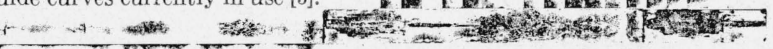

maximum travel of the valve and caused it to remain open for $45^{\circ}$ instead of $34^{\circ}$ of the compression stroke. Compression pressures were also recorded.

Under both standard conditions, air consumption decreased slightly faster than the chamber pressure. Increasing the venturi diameter from $9 / 16$ in. to $3 / 4$ in. produced a 10-percent increase in volumetric efficiency for the Motor Method, but only about 3 percent for the Research Method. This was the equivalent of restoring sea-level air consumption at $27 \mathrm{in}$. and $29 \mathrm{in} . \mathrm{Hg}$ in the two methods, respectively. The high-lift camshaft made no improvement under Motor Method conditions and caused a slight decrease in Research Method volumetric efficiency. An Aviation Method curved inlet elbow also proved to be of no value for this purpose. An increase in exhaust back pressure decreased air consumption. Compression pressure was always proportional to air consumption when no excess back pressure was used.

\section{Individual Effects of Engine Operating Variables}

In these experiments the engine was run with all operating conditions standard except that being investigated.

\section{(a) Exhaust Back Pressure}

An increase of 9 -in.- $\mathrm{Hg}$ exhaust back pressure caused an apparent increase of about one octane unit in the Motor Method rating, while in the Research Method, rating was decreased approxi- mately the same amount. Engine operation was extremely rough and erratic.

\section{(b) Engine Speed}

In order to determine the effect of engine speed on octane number ratings, the engine was run under standard Motor Method conditions, except that its speed was reduced from 900 to 600 rpm. Fuels $1,4,5,6$, and 7 were rated at $21 \mathrm{in}$. $\mathrm{Hg}$, and in all cases it was necessary to decrease the compression ratio below that specified in the Motor Method guide curves in order to keep the detonation down to standard knock intensity.

All fuels except No. 4 showed an average increase in rating of about 6 octane units. Fuel 4 showed a decrease in rating of 2.4 octane units. Reducing the engine speed by $300 \mathrm{rpm}$ has a greater effect on the rating than does a decrease in pressure of 9 in. $\mathrm{Hg}$. However, the magnitude of the effect of speed varies greatly from fuel to fuel so that no single change in speed could be expected to have the same compensating effects for all fuels.

\section{(c) Inlet Temperature}

The effect of lowering intake gas temperature in $25^{\circ} \mathrm{F}$ increments was measured for the Motor Method. Fuels 2, 4, and 6 were run with the $3 / 4$-in. venturi at 21 in. Hg. Fuels 2 and 6 rated about one octane unit higher for every 25-deg drop in manifold temperature. The rating of fuel 4 changed in the opposite direction by about one octane unit for every 50-deg drop in temperature.

No experiments were made with lower inlet temperature for the Research Method because the standard temperature of $125^{\circ} \mathrm{F}$ is considered to be just adequate for vaporization of a $400^{\circ} \mathrm{F}$ end-point gasoline [4].

\section{(d) Ignition Timing}

The effect of spark advance on Research Method ratings was determined at 21 in. $\mathrm{Hg}$ for fuels 4,8 , and 9 . Results indicate that a change in timing cannot cause any significant increase in ratings at low pressures.

\section{(e) Knock Intensity}

The next independent variable to be tried was knock intensity. At 21 in. $\mathrm{Hg}$, fuels 4 and 8 were rated by the Research Method at standard micrometer settings and at setting $0.045 \mathrm{in}$. and $0.090 \mathrm{in}$. below the guide curve. The higher compression ratios gave much higher knock intensities, which lowered the rating of fuel 4 by about one octane unit and increased that of fuel 8 by about 0.2 unit.

\section{(f) Bouncing Pin Setting Adjustment}

Attempts were made to restore Research Method octane number ratings at $24 \mathrm{in}$. $\mathrm{Hg}$ of fuels $4,5,6,7$, and 8 to their sea-level values by adjusting the bouncing pin. No consistent improvement seems possible by use of this technique. 


\section{Conclusions}

All of the fuels tested in this program changed in octane rating as the pressure of the altitude chamber was decreased. In general, the fuels that were the most sensitive to altitude changes were those with the highest sensitivity to engine severity, as defined by the differences between their Motor Method and Research Method ratings. This is to be expected, as the higher compression ratios used at lower chamber pressures increase the engine severity by raising the compression temperatures.

It has been shown that decreased inlet temperature and decreased speed shift altitude ratings by the Motor Method toward their sea-level values, but at different rates for various fuels. Although the effects of spark advance on this method were not investigated, a change in this factor might prove advantageous. Larger carburetor venturis have proved useful, and permit ratings to be maintained at about their sea-level values up to altitudes to 3,000 to 4,000 $\mathrm{ft}$. It is possible that the Motor Method ratings are capable of being equalized throughout the altitude range by use of a suitable combination of changed conditions.

The Research Method, on the other hand, does not lend itself well to modifications of this type. The spark advance is already nearly the optimum, inlet temperature is at about the minimum that will assure adequate vaporization of the fuel, the volumetric efficiency is improved very little by use of a larger venturi, and the engine speed is already very low.

It appears, therefore, that the surest way of making the engine severity equal to that at sea level, regardless of the altitude, is to supercharge the inlet and throttle the exhaust, thereby simulating sea-level conditions. For this purpose, a small single-stage centrifugal compressor would probably suffice. The air would enter the blower through a standard humidity-controlling ice tower, and thence through the standard air heater to a pressurized carburetor. It is possible that an after-cooler may also be necessary to keep the inlet temperature below $125^{\circ} \mathrm{F}$ in the Research Method at the lower chamber pressures.

This investigation was carried out in cooperation with the Octane Correlation Advisory Committee of the Division of Refining of the American Petroleum Institute. Members of this committee are: Bruno R. Siegel, chairman, Frank C. Burk, Carl E. Habermann, J. E. Taylor; associate members are Harold M. Trimble, H. R. Stacey, John M. Snell, Afton D. Puckett, and Hudson W. Kellogg. Appreciation is expressed to the committee members for planning the scope of the work and their expert advice in carrying it out. Credit is also due the following for their work in operating the engines and altitude equipment: W. C. Lacey, Myron C. Wolfe, James O. Chase, H. B. Dickerson, J. M. Mealing, L. J. Wilson, H. S. Simmons, Fred W. Ramin, George J. Miner, Edwin H. Rich, Richard M. David, James A. Walker, Milford Barnes, Thomas W. Mears, and Mrs. Cecil S. Dussinger.

\section{References}

[1] W. M. Holaday and G. T. Moore, Effect of altitude on octane number determination, presented at SAE Annual Meeting, January 1937.

[2] D. B. Brooks, Effect of altitude on knock rating in CFR engines, J. Research NBS 28, 713 (1942) RP1475.

[3] ASTM manual of engine test methods for rating fuels and 1948 appendix (American Society for Testing Materials, 1916 Race Street, Philadelphia 3, Pa.).

[4] O. C. Bridgeman, Equilibrium volatility of motor fuels from the standpoint of their use in internal combustion engines, J. Research NBS 13, 53 (1934) RP694.

Washington, April 10, 1950.

\title{
Creep of High-Purity Copper
}

\section{By William D. Jenkins and Thomas G. Digges}

\begin{abstract}
Creep tests were made at $110^{\circ}, 250^{\circ}$, and $300^{\circ} \mathrm{F}$ on annealed oxygen-free high-conductivity copper. The rate of loading to the ultimate had a significant effect on the amount of plastic extension and thereby affected the creep behavior. The strain rate during the so-called second stage of approximately constant rate was not constant but varied in a cyclic manner. A less-pronounced cyclic variation was also evident in both the first and third stages. The beginning of the third stage was often accompanied by microcracking, but in other tests this stage was initiated without the presence of such cracks. The parent grains were fragmented during creep, and strain markings were observed in all specimens carried to complete fracture.
\end{abstract}

\section{Introduction}

Creep tests in tension were made on annealed oxygen-free high-conductivity copper as a part of a continuing investigation at this Bureau on the creep of metals and alloys. Additional tests at elevated and subzero temperatures on this copper and other materials are in progress. In a previous paper $[1]^{1}$ it was shown that the flow, ultimate and fracture

\footnotetext{
1 Figures in brackets indicate the literature references at the end of this paper.
} 